\title{
PENERAPAN KETERAMPILAN MANAJEMEN KELAS DALAM PEMBELAJARAN PENDIDIKAN AGAMA ISLAM DI MI MASYARIKUL ANWAR 4 BANDAR LAMPUNG
}

\author{
Nurul Hidayah \\ nurul.hidayah@radenintan.ac.id
}

\begin{abstract}
Class management refers to activities that create and maintain optimal conditions for the occurrence of the teaching-learning process that requires the effectiveness of learning, this is because it can affect the learning achievement of students to be achieved by the students themselves. Thus class management has an important role in increasing the learning effectiveness of students that is trying as much as possible so that students have a high learning motivation for all teaching.

Classroom management has an important role in increasing the learning effectiveness of students and school facilities which is trying as much as possible so that students have a high learning motivation for all teaching and effort to meet the needs of students well. The method used is a description of the analysis with a qualitative approach. This study aims to determine the Application of Class Management Skills in Learning Islamic Education in MI Masyarikul Anwar 4 Bandar Lampung.

It can be concluded that the results of the application of classroom management skills in PAI learning at MI Masyarikul Anwar 4 Bandar Lampung that the skills in managing the class have been implemented well but need to be improved in the regulation of students because there are still some indicators that have not been implemented in accordance with school goals.
\end{abstract}

\begin{abstract}
Abstrak
Manajemen kelas merujuk kepada kegiatan-kegiatan yang menciptakan dan mempertahankan kondisi yang optimal bagi terjadinya proses belajar-mengajar dibutuhkan adanya efektivitas pembelajaran, hal ini dikarenakan dapat mempengaruhi prestasi belajar peserta didik yang akan dicapai oleh peserta didik itu sendiri. Dengan demikian manajemen kelas memiliki peranan penting dalam meningkatkan efektivitas belajar peserta didik yaitu berusaha semaksimal mungkin agar peserta didik memiliki motivasi belajar yang tinggi terhadap semua pengajaran.

Pengelolaan kelas memiliki peranan penting dalam meningkatkan efektifitas belajar peserta didik dan fasilitas sekolah yaitu berusaha semaksimal mungkin agar peserta didik memiliki motivasi belajar yang tinggi terhadap semua pengajaran dan usaha untuk memenuhi kebutuhan peserta didik dengan baik. Metode yang digunakan yaitu Deskripsi Analisis dengan pendekatan kualitatif. Penelitian ini bertujuan untuk mengetahui Penerapan Keterampilan Manajemen Kelas Dalam Pembelajaran Pendidikan Agama Islam Di MI Masyarikul Anwar 4 Bandar Lampung.

Dapat disimpulkan hasil penelitian penerapan keterampilan manajemen kelas dalam pembelajaran PAI di MI Masyarikul Anwar 4 Bandar Lampung bahwa keterampilan dalam memanajemen kelas sudah terlaksana dengan baik tetapi perlu ditingkatkan lagi pada pengaturan peserta didiknya karena masih terdapat beberapa indikator yang belum berjalan sesuai dengan tujuan sekolah.
\end{abstract}

Kata kunci: Manajemen Kelas, Pembelajaran, Pendidikan Agama Islam. 


\section{A. PENDAhuluan}

Manajemen kelas adalah rentetan kegiatan guru untuk menumbuhkan dan mempertahankan organisasi kelas yang efektif, yaitu meliputi: tujuan pengajaran, pengaturan waktu, pengaturan ruangan dan peralatan, dan pengelompokkan siswa dalam belajar.

Pengertian yang berbeda manajemen kelas adalah berbagai jenis kegiatan yang sengaja dilakukan oleh guru dengan menciptakan dan mempertahankan kondisi yang optimal bagi terjadinya proses belajar-mengajar. Manajemen kelas adalah suatu upaya memberdayagunakan potensi kelas yang ada seoptimal mungkin untuk mendukung proses interaksi edukatif mencapai tujuan pembelajaran.

Manajemen kelas adalah suatu usaha yang dengan sengaja dilakukan guna mencapai tujuan pengajaran. Kesimpulan yang sangat sederhana adalah, bahwa pengelolaan kelas merupakan kegiatan pengaturan kelas untuk kepentingan pengajaran. Tujuan pengelolaan kelas adalah agar setiap anak di kelas dapat bekerja dengan tertib sehingga segera tercapai tujuan pengajaran secara efektif dan efisien.Oleh karena itu, diperlukan manajemen kelas yang baik sehingga tujuan pembelajaran dapat tercapai. Karenanya manajemen kelas memegang peranan yang sangat menentukan dalam pembelajaran.

Peningkatan mutu pendidikan sekolah perlu didukung kemampuan mengelola dan melaksanakan manajemen kelas. Sekolah ataupun kelas perlu berkembang maju dari tahun ke tahun. Karena itu, hubungan baik guru dengan murid perlu diciptakan agar terjalin iklim dan suasana pembelajaran yang kondusif dan menyenangkan. Demikian halnya penataan penampilan fisik dan kelas perlu dibina agar kelas menjadi lingkungan pendidikan yang dapat menumbuhkan kreativitas, disiplin dan semangat belajar peserta didik. Dalam hal ini berkaitan dengan pendidikan karena pada dasarnya manajemen kelas merupakan bagian dari kegiatan pendidikan. Pendidikan memiliki pengertian usaha manusia untuk melakukan dengan penuh tanggungjawab membimbing anak didik, hal ini seperti pendapat Sumadi (2013:293).

Pendidikan adalah usaha manusia (pendidik) untuk melakukan dengan penuh tanggung jawab membimbing anak-anak didik ke kedewasaan Sumadi (2013:293). Seperti halnya dalam pendidikan agama bahwasannya pendidikan ditujukan untuk membimbing anak agar mengerti nilai-nilai ajaran agama kemudian mampu menyelaraskan dan mengamalkannya ke dalam kehidupan bermasyarakat. Masalah pokok yang dihadapi guru, baik pemula maupun yang sudah berpengalaman adalah pengelolaan kelas. Karena pengelolaan kelas merupakan masalah yang kompleks. Guru menggunakannya untuk menciptakan dan mempertahankan kondisi kelas untuk mencapai tujuan pengajaran secara efisien dan memungkinkan anak didik belajar Syaiful Bahri Djamarah dan Aswan Zain (2014:173). Pengelolaan kelas merupakan bagian integral dari kemampuan profesional yang harus dimiliki oleh seorang guru, mengelola kelas merupakan salah satu keterampilan dasar mengajar yang bertujuan untuk mewujudkan dan mempertahankan suasana pembelajaran yang optimal Sunhaji (2014).

Kedudukan guru mempunyai arti penting dalam pendidikan. Arti penting itu bertolak dari tugas dan tanggung jawab guru yang cukup berat untuk mencerdaskan anak didiknya. Kerangka berpikir yang demikian menghendaki seorang guru untuk melengkapi dirinya dengan berbagai keterampilan yang diharapkan dapat membantu dalam menjalankan tugasnya dalam interaksi edukatif. Keterampilan dasar mengajar adalah keterampilan yang mutlak harus guru punyai dalam hal ini. Dengan pemilikan keterampilan dasar mengajar ini diharapkan guru dapat mengoptimalkan peranannya di kelas."Keterampilan mengelola kelas adalah kemampuan guru dalam menciptakan dan memelihara iklim pembelajaran yang optimal serta keterampilan dalam mengendalikan kondisi belajar yang optimal" Fatimah Kadir (2014)

Pembelajaran merupakan suatu proses yang kompleks dan melibatkan berbagai aspek yang kreatif, dan menyenangkan, diperlukan berbagai keterampilan. Diantaranya adalah keterampilan membelajarkan atau keterampilan mengajar. Dalam arti guru harus selalu menciptakan suasana yang kondusif dalam lingkungan pendidikan dan menjalankan tugasnya di dalam kelas dengan semaksimal mungkin demi tercapainya tujuan pendidikan.Guru memiliki peranan yang sangat sentral, baik sebagai perencana, pelaksana, maupun evaluator pembelajaran. Maka seorang guru hendaknya tidak memiliki pandangan bahwa mengajar hanya merupakan tugas yang telah menjadi kebiasaan sehingga dia terpaku dengan cara dan gaya lama, tidak ada dinamika. Tetapi sebaliknya, guru diharapkan untuk selalu melakukan inovasi dan kreativitas untuk mengembangkan proses pembelajaran kearah yang lebih baik, efektif dan efisien. Keterampilan mengajar merupakan faktor dasar yang harus dimiliki oleh seorang guru untuk meningkatkan mutu pengajaran, diantaranya adalah keterampilan pengelolaan kelas yang penting diperhatikan oleh seorang guru untuk meningkatkan mutu pengajaran dalam menghadapi peserta didiknya.

Berdasarkan hasil wawancara pada saat Pra Survey dengan Kepala Sekolah MI Masyarikul 
Anwar 4 Bandar Lampung beliau selalu berusaha secara maksimal dalam Penerapan Keterampilan Manajemen Kelas Dalam Pembelajaran Pendidikan Agama Islam, hal ini terlihat pada wawancara bahwa Guru PAI dan staff MI Masyarikul Anwar Bandar Lampung, selalu berusaha menjalankan manajemen kelas dengan baik melalui pengaturan ruangan, pengaturan letak duduk, pengaturan Ventilasi dan cahaya, serta pengaturan dan penyimpangan peralatan seperti LCD Proyektor dan media pembelajaran yang lainnya.

Namun saat melakukan Pra Survey dilapangan yang dengan cara observasi langsung terhadap pelaksanaan pengelolaan kelas di MI Masyarikul Anwar 4 Bandar Lampung yaitu dalam indikator pengaturan peserta didik, guru dalam mengendalikan tingkah laku dan guru dalam mengatur kedisiplinan masih kurang baik, dan dalam indikator pengaturan fasilitas, guru kurang memperhatikan penempatan letak duduk peserta didik.

Dari data prasurvey dapat ditarik kesimpulan bahwasannya guru belum maksimal dalam mengelola kelas karena masih ada pengelolaan kelas yang belum dilaksanakan sepenuhnya baik yaitu dalam mengendalikan tingkah laku peserta didik, mengatur kedisiplinan peserta didik dan kurang memperdulikan pengaturan penempatan letak duduk, begitu juga persoalan yang dihadapi peserta didik mulai dari berkeliling kelas, membuat suasana gaduh, tidak memakai atribut yang lengkap. Dari keduanya tersebut faktor lingkungan juga mempengaruhi proses pembelajaran, karena lingkungan yang kondusif juga besar pengaruhnya dalam menentukan keberhasilan proses belajar. Tujuan utama dari penelitian ini adalah untuk mengetahui Penerapan Keterampilan Manajemen Kelas Dalam Pembelajaran Pendidikan Agama Islam Di MI Masyarikul Anwar 4 Bandar Lampung PAI di MI Masyarikul Anwar 4 Bandar Lampung.

\section{B. TUJUAN PENELITIAN}

Tujuan dalam penelitian ini adalah untuk mengetahui Penerapan Keterampilan Manajemen Kelas Dalam Pembelajaran Pendidikan Agama Islam Di MI Masyarikul Anwar 4 Bandar Lampung.

\section{METODE PENELITIAN}

Teknik analisis data dalam penelitian ini adalah proses mencari dan menyusun secara sistematis data yang diperoleh dari hasil wawancara, catatan lapangan, dan dokumentasi dengan cara mengorganisasikan data kedalam kategori, melakukan sintesa, menyusun kedalam pola, memilih mana yang penting dan yang akan dipelajari, dan membuat kesimpulan sehingga mudah difahami oleh diri sendiri dan orang lain. Dan adapun langkah-langkah dalam menganalisis data yaitu langkah pertama Reduksi data atau diartikan merangkum, memilih, hal-hal yang pokok, memfokuskan pada hal-hal yang penting, dicari tema dan polanya. dan membuang yang tidak perlu, dalam kaitan ini peneliti perlu menajamkan.

Penelitian ini merupakan jenis penelitian kualitatif. Menurut Lexy J. Moleong (2013:4) menjelaskan penelitian kulitatif adalah sebagai tradisi tertentu dalam ilmu pengetahuan sosial yang secara fundamental bergantung pada pengamatan pada manusia dalam kawasannya sendiri dan berhubungan dengan orang-orang tersebut dalam bahasanya dan dalam peristilahannya. Penelitian yang dilakukan adalah dengan menggunakan metode deskriptif analisis melalui penelitian lapangan, yaitu mendeskripsikan atau menjelaskan sesuatu hal seperti apa adanya sehingga memberi gambaran yang jelas tentang situasi-situasi di lapangan.

Dalam penelitian ini, pengumpulan data dilakukan dengan metode observasi, wawancara dan dokumentasi, instrumen yang digunakan dalam penelitian ini berupa kisi-kisi lembar observasi, kisi-kisi wawancara, dan kisi-kisi dokumentasi, Pengujian instrumen dilakukan dengan menggunakan uji keabsahan, yakni dengan membandingkan isi instrumen dengan teori yang ada.

Analisis, menggolongkan atau pengkategorisasian ke dalam tiap permasalahan melalui uraian singkat, mengarahkan, membuang yang tidak perlu, dan mengorganisasikan data sehingga kesimpulankesimpulan finalnya dapat ditarik dan diverifikasi, langkah kedua Display Data atau penyajian data yang dilakukan dalam bentuk uraian singkat, dan menyusun data yang relevan sehingga menjadi informasi yang dapat disimpulkan dan juga memiliki makna tertentu, dan selanjutnya langkah ketiga yaitu Conclusion Drawing atau kesimpulan dan verifikasi yaitu, Kesimpulan awal yang dikemukakan masih bersifat sementara, dan akan berubah bila tidak ditemukan bukti-bukti yang kuat yang mendukung pada tahap awal, didukung oleh bukti-bukti yang valid dan konsisten saat peneliti kembali ke lapangan mengumpulkan data, maka kesimpulan yang dikemukakan merupakan kesimpulan yang kredibel.

Dengan demikian kesimpulan dalam penelitian kualitatif mungkin dapat menjawab rumusan masalah yang dirumuskan sejak awal, tetapi mungkin juga tidak, karena seperti telah dikemukakan bahwa masalah dan rumusan 
masalah dalam penelitian kualitatif masih bersifat sementara dan akan berkembang setelah penelitian di lapangan. Jelaslah bahwa analisa induktif tersebut bertitik tolak dari perihal khusus kemudian ditarik kesimpulannya yang bersifat umum sehingga kesimpulan tersebut berlaku secara umum. Artinya dalam penelitian ini penulis menganalisa permasalahanpermasalahan yang ada secara khusus kemudian menyimpulkan secara umum.

\section{HASIL DAN PEMBAHASAN}

\section{Manajemen Kelas Dalam Pembelajaran PAI Di MI Masyarikul Anwar 4 Bandar Lampung.}

Pada bagian ini penulis melakukan pengolahan data yang kemudian dianalisa dan terakhir diambil kesimpulan, dalam hal ini penulis menggunakan metode observasi, interview, dan dokumentasi yang berusaha untuk memperoleh data tentang manajemen kelas dalam pembelajaran PAI di MI Masyarikul Anwar 4 Bandar Lampung. Adapun Hasil yang diperoleh yaitu:

Pertama: untuk mencapai tujuan pengajaran, guru mampu mengorganisasi materi pelajaran. Dapat dilihat dari hasil observasi penulis terhadap guru ketika menyampaikan materi pelajaran kepada peserta didik menunjukan adanya kemampuan dalam menguasai bahan pelajaran. Penggunaan media dan sumber belajar dapat dilihat dari keterampilan guru saat pembelajaran. Kemampuan mengelola proses belajar-mengajar dapat dilihat pada saat menerangkan materi pelajaran suasana kelas dalam keadaan tenang dan tidak gaduh.Kemampuan memberiakan evaluasi belajar, terlihat pada saat guru selesai memberikan materi pelajaran, guru tersebut mengevaluasi terhadap materi yang diajarkan. Dan didalam penyampaian materi dalam perencanaan pembelajaran terlebih dahulu guru menyiapkan perangkat pembelajaran dengan maksimal, seperti prota, promes, silabus, dan RPP dan di dalam penyampaian materi pembelajaran guru selalu mengaitkan dengan fenomena/kejadian yang ada. Hal ini dilakukan dalam rangka mengarahkan siswa agar peduli terhadap lingkungan sekitar. Serta memudahkan pemahaman siswa terhadap materi.

Kedua: didalam proses belajar-mengajar guru sudah memanfaatkan waktu dengan cukup baik, sebelum memulai pelajaran terlebih dahulu membuat RPP yang terdapat didalamnya tahapan-tahapan penggunaan waktu. Di mana dalam proses belajar-mengajar selalu mengadakan preetes 20 menit, mengulas pelajaran minggu lalu 10 menit, inti materi 20/15 menit, dan diakhiri dengan postes kemudian penutup. Hal ini menunjukan keantusiasan guru dalam pembelajaran.
Adapun langkah-langkah proses belajarmengajar di MI Masyarikul Anwar 4 Bandar Lampung yang terjadi ialah :

1)Guru mencatat kehadiran siswa dan mencatat siapa yang tidak hadir, tidak perlu diabsen satu per satu, cukup ditanya yang tidak hadir sajadengan alasannya.

2)Bertanya kepada siswa sampai dimana pembahasan pelajaran sebelumnya.

3)Mengajukan pertanyaan kepada siswa tentang bahan pelajaran yang sudah diberikan sebelumnya.

4)Memberi kesempatan kepada siswa untuk bertanya mengenai bahan pelajaran yangbelum dikuasainya dari pengajaran yang telah dilaksanakan sebelumnya.

5)Mengulang kembali bahan pelajaran yang lalu secara singkat tapi mencakup semua aspek bahan yang telah dibahas sebelumnya.

Ketiga: dalam pengaturan fasilitas, pembelajaran yang efektif dapat bermula dari iklim kelas yang dapat menciptakan suasana belajar yang menggairahkan, untuk itu diperlukan perhatian terhadap pengaturan atau penataan ruang kelas dan isinya, selama proses pembelajaran. Lingkungan kelas perlu ditata dengan baik sehinggamemungkinkan terjadinya interaksi yang aktif antara siswa dengan guru, dan antar siswa.

Berdasarkan hasil observasi penulis di MI Masyarikul Anwar 4 Bandar Lampung, di dalam pengaturan ruangan (fasilitas) guru telah menata lingkungan fisik seperti:1)Visibility (keleluasaan pandangan)Visibility artinya penempatan dan penataan barang-barang di dalam kelas agar tidak mengganggu pandangan siswa, sehingga siswa secara leluasa memandang guru. Begitu pula guru dapat memandang semua siswa dalam kegiatan pembelajaran.2)Accesibility (mudah dicapai)Penataan ruang dapat memudahkan siswa untuk meraih atau mengambil barangbarang yang dibutuhkan selama proses pembelajaran. Selain itu jarak antar tempat duduk cukup untuk dilalui oleh siswa sehingga siswa dapat bergerak dengan mudah dan tidak mengganggu siswa lain yang sedang bekerja.3)Fleksibilitas (keluwesan)Barangbarang di dalam kelas mudah ditata dan dipindahkan disesuaikan dengan kegiatan pembelajaran. Seperti penataan tempat duduk yang perlu diubah jika proses pembelajaran menggunakan metode diskusi, dan kerja kelompok.4)Kenyamanan Kenyamanan disini berkenaan dengan temperatur ruangan, cahaya, suara, dan kepadatan kelas.

Berdasarkan hasil interview dengan siswa yaitu Agus rahman salah satu peserta didik di MI Masyarikul Anwar 4 Bandar Lampung mengatakan: "kami sebelum memulai pelajaran terlebih dahulu berdoa dan membereskan kelas setiap hari secara bergantian sesuai jadwal piket 
yang sudah ditentukan secara bersama selain itu melalukan kegiatan pemanasan pikiran dengan tes konsentrasi antar siswa dengan suasana yang menyenangkan "Hal tersebut menunjukan bahwasanya di MI Masyarikul Anwar 4 Bandar Lampung sudah terjalin komunikasi yang baik. Dimana dapat dilihat dari penataan berangbarang di dalam kelas tidak mengganggu pandangan siswa, sehingga siswa secara leluasa dapat memandang guru dan sebaliknya guru dapat memandang semua siswa dalam kegiatan pembelajaran.

Keempat: berdasarkan hasil observasi diperoleh data bahwa guru di MI Masyarikul Anwar 4 Bandar Lampung dalam pembelajaran PAI sering mengelompokan siswa dalam belajar, beliau menyatakan agar siswa tidak selalu bergantung kepada guru, hal ini juga dapat melatih kemampuan komunikasi dengan cara mengembangkan kemampuan menggunakan ide atau gagasan, membantu siswa untuk rispek kepada temannya dan dapat meningkatkan prestasi akademik siswa, serta meningkatkan motivasi dan rangsangan untuk berfikir.

Berdasarkan pengamatan di lapangan, guru tidak sekedar mengelompokan siswa dalam belajar, tetapi guru menunjukan : (1) sikap positif terhadap siswa, hal ini terlihat ketika memberikan perhatian kepada seluruh siswa yang mengalami kesulitan. Bantuan ini diberikan apabila peserta didik sudah berusaha tetapi masih belum berhasil. Bantuan tersebut bukan berarti memecahkan masalah yang dihadapi siswa, melainkan memberikan saran tentang jalan keluarnya, memberikan dorongan dan membangkitkan motivasi agar peserta didik memiliki keberanian untuk mengemukakann ide atau gagasan, mengemukakan pendapat, keterampilan berbicara dan berfikir bebas tanpa harus takut salah di depan kelas. (2) keluwesan dalam pendekatan pembelajaran, hal ini dapat terlihat ketika guru mengamati tingkah laku siswa, mengumpulkan data tentang siswa, mengenal siswa yang memerlukan bantuan lebih, mengadakan pertemuan atau hubungan dengan orang tua siswa, dan menyelenggarakan bimbingan kelompok atau individu. (3) pemberian nilai yang adil, hal ini dapat terlihat ketika guru bersifat objektif tidak memandang dan membeda-bedakan latar belakang peserta didik, namun melihat kompetensi yang dihasilkan oleh peserta didik tersebut. Penilaian dilaksanakan secara objektif dan tidak dipengaruhi oleh subyektivitas penilaian.

Berdasarkan hasil observasi, interview dan dokumentasi diketahui juga bahwa peranan lain yang dilaksankan guru dalam manajemn kelas sebagaimana fungsinya dalam pembelajaran PAI sebagai berikut :Pertama, perencanaan kelas yaitu membuat RPP (Rencana Pelaksanaan Pembelajaran). Hal ini bertujuan untuk mengetahui tentang arah, tujuan, tindakan, sumber daya, sekaligus metode atau teknik yang tepat untuk digunkaan guru dalam proses belajar-mengajar di kelas.

Kedua,melakukan pengorganisasian kelas. melaksanakan pengorganisasian kelas berkaitan dengan pengaturan sumber daya yang akan digunakan baik berupa pengaturan manusia ataupun pengaturan fasilitas. Pengaturan manusia dengan cara membagi peserta didik kedalam kelompok belajar dengan kemampuan yang bervariasi, dan menentukan tugas masingmasing peserta didik atau kelompok belajar agar mereka memiliki tanggung jawab masingmasing. Sedangkan pengaturan fasilitas yaitu seperti pengaturan penempatan tempat duduk, penempatan perpustakaan, papan tulis, dan hiasan-hiasan dinding yang memiliki nilai pendidikan, dan lain sebagainya.

Ketiga, kepemimpinan kelas. Dalam proses pembelajaran gurulah sebagai leader maka guru haruslah memiliki jiwa pemimpin, hal ini agar guru memiliki karakter yang berbeda-beda karena sebagai pemimpin bukan saja mengatur kelas namun harus mampu mengarahkan, membimbing, dan memotivasi peserta didik dalam belajar.Keempat, pengendalian dalam kelas. Saat proses belajar mengajar berlangsung agar tidak terjadi penyimpangan yang tidak diinginkan maka guru harus mengawasi proses belajar mengajar yang berlangsung agar sesuai dengan tujuan pembelajaran.

\section{Pengaturan Peserta Didik}

\section{a. Pengendalian Tingkah Laku}

Usaha guru PAI dalam mengatur pengendalian tingkah laku adalah dengan cara membangkitikan motivasi siswa dalam belajar, sehingga siswa tidak merasa jenuh dan tidak merasa saling terganggu. Dalam observasi terhadap pelaksanaan proses belajar mengajar di kelas, dimana guru menciptakan proses belajar mengajar dengan cara yang diharapkan namun kenyataannya masih saja ada peserta didik yang berkeliling kelas dan membuat suasana gaduh, sehingga membuat peserta didik yang lain merasa terganggu, artinya disini guru belum dapat mengendalikan tingkah laku secara maksimal. Seharusnya guru dapat mengoptimalkannya dengan melakukan suatu tindakan agar siswa tidak melenceng dari nilainilai norma, dengan cara menegur peserta didik dan memberikan ketegasan kepada mereka agar suasana belajar menjadi kondusif, menyenangkan, dan berjalan dengan lancar sesuai dengan yang di harapkan.

\section{b. Pengaturan Kedisiplinan}

Kenyataan yang ditemukan tentang masalah kedisiplinan di MI Masyarikul Anwar 4 dalam 
observasi yaitu, peraturan kedisiplinan di kelas sudah diatur sejak awal pertemuan dan sudah disepakati bersama, yaitu peraturan-peraturan yang ada di dalam kelas, diantaranya peserta didik wajib memakai seragam, peserta didik tidak boleh terlambat lebih dari waktu yang telah ditemukan, pesera didik tidak boleh absen tanpa alasan yang jelas, peserta didik dilarang berkelahi atau membuat gaduh di kelas apalagi saat proses belajar mengajar sedang berlangsung, akan tetapi masih saja ada peserta didik yang melanggar peraturan tersebut, yaitu datang terlambat, masih ada yang meengenakan jaket saat pembelajaran berlangsung, dan tidak memakai atribut yang lengkap, artinya dapat dikatakan kedisiplinan peserta didik belum berjalan secara maksimal karena kurang tegasnya seorang guru dalam memperhatikan kedisiplinan peserta didik sehingga masih ada yang melanggar peraturan. Seharusnya guru mempunyai aturan yang dapat mengefekjerakan bagi yang melanggar peraturan dengan cara membuat peserta didik merasa jera dan takut dengan adanya hukuman yang berlaku, dan jika itu juga tidak mereka hiraukan maka guru dapat melaporkan ke guru bimbingan konseling. Peraturan kedisiplinan di kelas ini bertujuan untuk mengefekjerakan bagi pelanggar peraturan dan melatih tanggung jawab setiap peserta didik serta membentuk prosedur kelas sehingga pembelajaran dapat berlangsung dengan baik.

\section{c. Minat/Perhatian Peserta Didik}

Untuk memfokuskan perhatian/minat belajar di kelas salah satu cara untuk mengatasinya yaitu dengan menciptakan variasi dalam mengajar, seperti bercerita, membuat pemainan yang berhubungan dengan materi saat itu sehingga siswa akan memperhatikan materi yang disampaikan oleh guru dan menjadikan suasana pembelajaran lebih menyenangkan dan peserta didik tidak merasa bosan saat guru sedang menjelaskan materi yang disampaikan. Dan guru dituntut selalu memiliki kreativitas dan inovasi terbaru agar dapat menciptakan dan mempertahankan kondisi belajar yang menyenangkan sesuai dengan tujuan pembelajaran yang diharapkan.

\section{d. Gairah Belajar Peserta Didik}

Kreativitas guru dalam mengajar akan membuat peserta didik semakin bersemangat dalam mengikuti proses belajar mengajar di dalam kelas. Cara guru dalam meningkatkan gairah belajar peserta didik dengan menggunakan pembelajaran yang komunikatif dan kreatif, seperti memberikan hadiah (Reward) yaitu berupa nilai tambahan bagi peserta didik yang masih mempunyai nilai yang masih kurang, sekaligus memotivasi rekanreknnya untuk berprestasi, serta memberikan nilai yang objektif sesuai pemberian tugas. Dapat dikatakan guru cukup baik dalam meningkatkan gairah belajar peserta didik.

\section{e. Dinamika Kelompok Peserta Didik}

Kegiatan yang dilakukan guru PAI di MI Masyarikul Anwar 4 terkait pengaturan kelompok adalah guru-guru PAI melakukan pembagian kelompok saat diskusi atau tugas rumah yaitu dengan membagi sesuai deretan tempat duduk. Terkadang langsung membagi secara acak dan juga sesuai keinginan peserta didik untuk memilih kelompoknya masingmasing. Pembentukan kelompok untuk kepentingan belajar sudah diterapkan oleh guru PAI di MI Masyarikul Anwar 4. Dan pembentukan kelompok tersebut diadakan pada saat pembelajaran dengan metode diskusi atau kegiatan kelompok belajar di rumah.

\section{Pengaturan Fasilitas}

a. Ruang Tempat Belajar

Pihak sekolah sudah memenuhi fasilitasfailitas penunjang proses belajar mengajar, Ruangan tempat belajar sudah memungkinkan semua peserta didik bergerak leluasa tidak berdesak-desakan dan tidak mengganggu pada saat melaksanakan aktivitas belajar. Dan untuk pengaturan ruang tempat belajar memang sudah diatur sejak pembangunan sekolah.

\section{b. Pengaturan Tempat Duduk}

Salah satu kenyataan yang ditemukan adalah tentang masalah pengaturan tempat duduk di MI Masyarikul Anwar 4. Peraturan tempat duduk di kelas sudah diatur sejak awal pertemuan namun siswa diberi kebebasan untuk duduk dimana saja dan dengan siapa, guru tidak mengatur untuk soal penempatan duduk seperti siswa yang kurang pandai di depan, siswa yang sedang di tengah dan siswa yang pandai dibelakang, guru menyamaratakan tidak ada yang di beda-bedakan, tetapi pada kenyataanya guru tidak memperdulikan ketika tempat duduk dibagian depan kosong seharusnya guru cepat tanggap dalam hal seperti ini yaitu dengan memerintahkan peserta didik untuk berpindah dan mengisi tempat duduk dibagian depan yang kosong tersebut sehingga tetap berjalan dengn lancar saat pembelajaran sedang berlangsung. Karena, Pengaturan tempat duduk bertujuan untuk memungkinkan terjadinya tatap muka, dengan demikian guru dapat mengontrol tingkah laku peserta didik. 


\section{c. Ventilasi dan Pengaturan Pencahayaan}

Ventilasi dan pengaturan cahaya adalah aset penting untuk terciptanya suasana belajar mengajar yang nyaman. Oleh karena itu, Ventilasi harus cukup menjamin kesehatan peserta didik, dan ventilasi memang sudah diatur sejak pembangunan sekolah hanya saja kita harus membersihkan ventilasi setiap saat agar udara yang masuk terasa segar tidak ada debu karena debu sendiri telah disaring dengan adanya kain penyaring debu. Dapat disimpulkan bahwa pengaturan ventilasi di MI Masyarikul Anwar 4 sudah memadai, udara di setiap kelas terasa sejuk dan tidak terasa sesak/panas. Untuk pengaturan cahaya dan ventilasi sendiri memang sudah diatur dsejak pembangunan sekolah. Dan jika dalam ruang kelas terasa kurang terang saat proses belajar mengajar berlangsung maka tersedia beberapa lampu untuk membantu pencahayaan ketika cuaca sedang mendung. Sehingga peserta didik dapat melihat dengan jelas materi yang ditulis di papan tulis ataupun tidak mengganggu penglihatan sehingga menurunkan konsentrasi belajar mengajar.

\section{d. Pengaturan Penyimpanan Barang-barang}

Fasilitas yang dimiliki oleh sekolah sudah memberikan yang terbaik dalam menunjang proses pembelajaran agar tujuan pembelajaran tercapai. seperti setiap kelas kami atur ruang kelasnya agar dapat merasa nyaman, fokus memperhatikan dan mendengarkan gurunya ketika menjelaskan. Dan untuk penyimpanaan barang-barang (peralatan) pihak sekolah telah menyiapkan sebuah loker di setiap kelas, yang berguna untuk menyimpan barang-barang peserta didik yang sekiranya ingin di simpan. Maka dari itu pihak sekolah dapat dikatakan baik dalam mengatur penyimpanan barangbarang, diharapkan pihak sekolah yaitu kepala sekolah, guru dan peserta didik dapat merawat dan menjaga nya agar tetap terlihat rapih dan bersih.

\section{Pembahasan}

Dalam penelitiaan ini peneliti selama menjalankan penelitian di MI Masyarikul Anwar 4, yaitu Keterampilan Pengelolaan Kelas yang memang sudah di terapkan di sekolah tersebut, tetapi peneliti hanya melihat bagaimana guru dalam melaksanakan keterampilan pengelolaan kelas dalam pembelajaran Pendidikan Agama Islam, ternyata setelah peneliti melakukan observasi bahwasannya masih ada beberapa indikator yang belum berjalan secara maksimal yaitu dalam pengaturan peserta didik dan pengaturan fasilitas. Pertama, pengaturan peserta didik yaitu tingkah laku peserta didik dan kedisiplinan peserta didik. masih adanya peserta didik yang berkeliling kelas dan membuat suasana gaduh ketika guru sedang menjelaskan dan masih terdapat beberapa peserta didik yang belum mengikuti peraturan sekolah atau dikatakan tidak disiplin seperti tidak rapih dalam berpakaian yaitu baju tidak dimasukkan, masih ada yang memakai jaket didalam kelas dan tidak mengunakan atribut yang lengkap dan tidak sesuai dengan peatuan yang berlaku. Kedua, pengaturan fasilitas seperti pengaturan ruang tempat belajar, ventilasi, pencahayaan dan penyimpanan barang-barang peralatan sudah cukup baik diterapkan oleh pihak sekolah hanya saja masih kurangnya perhatian guru terhadap penempatan letak duduk yang belum diatur dan minimnya alat media seperti speaker jadi setiap guru bergantian menggunakannya.

Adapun upaya yang dilakukan untuk mengatasi masalah dalam implementasi keterampilan pengelolaan kelas adalah dengan cara menjalin kerjasama dengan seluruh guru, staf dan peserta didik serta mengadakan rapat bulanan agar dapat termonitoring sudah berjalan sesuai dengan tujuan atau belum.

\section{E. PENUTUP}

\section{1) KESIMPULAN}

Berdasarkan hasil penlitian serta penjelasan rumusan masalah pada bab sebelumnya, maka didapat kesimpulan penelitian sebagai berikut: Implementasi Keterampilan Pengelolaan Kelas dalam Pembelajaran PAI di MI Masyarikul Anwar 4 sudah teralisasi dengan baik tetapi perlu ditingkatkan lagi. Yaitu dalam pengaturan fasilitas (Fisik) yang terdiri dari pengaturan ruang belajar, pengaturan tempat duduk, pengaturan ventilasi udara, pengaturan cahaya dan pengaturan penyimpanan barang-barang.

\section{2) SARAN}

Meski demikian pengaturan pengelolaan kelas dalam pembelajaran PAI di MI Masyarikul Anwar 4 perlu ditingkatkan lagi terutama pada pengaturan peserta didik (Non Fisik) terdapat 2 faktor yang belum berjalan maksimal yaitu tingkah laku dan kedisiplinan. 


\section{DAFTAR PUSTAKA}

Asmadawati, "KeterampilanMengelolaKelas", Journa lLogaritma, Vol. 02 No. 02 Juli 2014.

Bahri Djamarah, Syaiful dan Aswan Zain, Strategi Belajar Mengajar,Jakarta : Rineka Cipta,2014.

E.Mulyasa. Menjadi Guru Profesional:Menciptakan Pembelajaran Kreatif danMenyenangkan,Bandung:PTRemajaRosdaka rya, 2013.

Husni El Hilali, "Pentingnya Pengelolaan Kelas dalam Pembelajaran", Journal PendidikanBiologi, Vol. 03 No. 01 Juli 2013.

J. Moleong, Lexy, Metodologi Penelitian Kualitatif, Bandung: Remaja Rosdakara,2013.

Ramayulis, Ilmu Pendidikan Islam, Jakarta: KalamMulia, 2015.

Fatimah

Kadir,

"KeterampilanMengelolaKelasdanImplementasi nyadalam Proses Pembelajaran", Journal AlTa 'dib, Vol. 07 No. 02 Juli 2014.

Sunhaji,

"KonsepManajemen KelasdanImplikasinyadala mPembelajaran".Journal Kependidikan, Vol. 02 No. 02 November 2014.

Suryabrata,Sumadi, $P$ sikologi

Pendidikan,Jakarta:RajaGrafindoPersada, 2013.

Thoifuri,MenjadiGuruInisiator,Semarang:Rasai 1,2013 .

Tim Dosen Administrasi Pendidikan Universitas Pendidikan Indonesia, Manajemen Pendidikan,Bandung: Alfabeta,2013.

Tohirin, Psikologi Pembelajaran Pendidikan Agama Islam, Jakarta: PT Raja GrafindoPersada, 2014.

Uzer Usman, Moh, Menjadi Guru Profesional, Bandung: PT Remaja Rosda Karya, 2016. 